\title{
Pemberdayaan Masyarakat Melalui Ekowisata pada Desa Pesisir di Kabupaten Bintan
}

\author{
Faizal Rianto', Billy Jenawi², Riau Sujarwani ${ }^{3}$ \\ Program Studi Administrasi Publik, Sekolah Tinggi Ilmu Sosial dam Ilmu Politik (STISIPOL) Raja Haji 1, 2,3 \\ faizalrianto@gmail.com ${ }^{1}$; billyjenawi08@gmail.com²; riausujarwani@gmail.com ${ }^{3}$
}

\begin{abstract}
Ecotourism activities and the community-based ecotourism model are not new in Bintan District. Some coastal villages such as the Village of Kuala Sempang through Ballond Mangrove Tour and the Village of Pengudang through Pengudang Bintan Mangrove are even able to promote the mangrove forest ecotourism activities managed by the local communities. The success in promoting tourism potential through the concept of ecotourism in these villages certainly brings the hope of empowerment to the communities. Some studies even emphasize that tourism with the concept of ecotourism and community-based ecotourism models can contribute positively and can be used as a means or tool for community empowerment, especially for economically marginalized local communities. However, so far, studies on tourism in Bintan District are more focused on aspects of managing ecotourism activities, evaluating the development of ecotourism, and studying the potential of mangroves, while studies on community empowerment through ecotourism activities are needed to be encouraged to provide understanding based on empirical evidence of the impact and benefits of ecotourism activities for community empowerment, especially in coastal villages. Therefore, this study aims to describe how ecotourism activities empower the communities in coastal villages in Bintan District.
\end{abstract}

Keywords: community empowerment; ecotourism; tourism; coastal villages.

\begin{abstract}
Abstrak
Kegiatan ekowisata dan model ekowisata berbasis masyarakat bukanlah hal yang baru di Kabupaten Bintan. Beberapa desa pesisir seperti Desa Kuala Sempang melalui Ballond Mangrove Tour, dan Desa Pengudang melalui Pengudang Bintan Mangrove, bahkan berhasil memajukan kegiatan ekowisata hutan mangrove yang dikelola oleh masyarakat setempat. Keberhasilan dalam memajukan potensi wisata melalui konsep ekowisata di desa-desa tersebut, tentu membawa harapan akan adanya pemberdayaan kepada masyarakat. Beberapa studi bahkan menegaskan bahwa pariwisata dengan konsep ekowisata dan model ekowisata berbasis masyarakat dapat berkontribusi secara positif serta dapat digunakan sebagai sarana atau alat bagi pemberdayaan masyarakat, khususnya bagi masyarakat setempat yang terpinggirkan secara ekonomi. Namun, sejauh ini, studi tentang pariwisata di Kabupaten Bintan lebih fokus pada aspek pengelolaan kegiatan ekowisata, evaluasi pengembangan ekowisata, serta kajian potensi mangrove, sedangkan kajian mengenai pemberdayaan masyarakat melalui kegiatan ekowisata masih perlu didorong untuk memberikan pemahaman berdasarkan bukti empiris akan dampak serta manfaat dari kegiatan ekowisata bagi pemberdayaan masyarakat, terutama di desa pesisir.
\end{abstract}




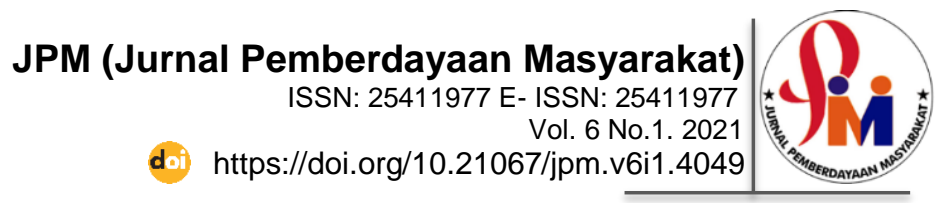

Oleh karenanya, penelitian ini bertujuan untuk mendeskripsikan bagaimana kegiatan ekowisata memberdayakan masyarakat pada desa-desa pesisir di Kabupaten Bintan.

Kata Kunci: pemberdayaan masyarakat; ekowisata; pariwisata; desa pesisir.

\section{A. PENDAHULUAN}

Konsep ekowisata dan model ekowisata berbasis masyarakat bukanlah hal yang baru di Kabupaten Bintan. Hal ini dikarenakan Pemerintah Daerah Kabupaten Bintan mendukung konsep ekowisata melalui Peraturan Daerah Kabupaten Bintan Nomor: 2 Tahun 2012 Tentang Rencana Tata Ruang Wilayah Kabupaten Bintan Tahun 2011-2031, dimana ditetapkan beberapa kawasan ekowisata di Kecamatan Teluk Bintan, Kecamatan Teluk Sebong, dan Kecamatan Gunung Kijang.

Beberapa studi juga menegaskan bahwa pariwisata dengan konsep ekowisata dan model ekowisata berbasis masyarakat dapat berkontribusi secara positif terhadap pemberdayaan masyarakat (Winkler dan Zimmermann, 2014) serta dapat digunakan sebagai sarana atau alat untuk pemberdayaan masyarakat, khususnya bagi masyarakat setempat yang terpinggirkan secara ekonomi (Garraway, 2008). Ekowisata juga dapat muncul sebagai wadah untuk memberikan kesempatan kepada masyarakat untuk mengelola dan memanfaatkan lingkungannya menjadi salah satu bagian wisata berbasis konservasi alam dan pendidikan lingkungan hidup (Nazarullail, Hardika, \& Desyanty, 2017).

Namun, sejauh ini, studi tentang pariwisata di Kabupaten Bintan lebih fokus pada aspek pengelolaan kegiatan ekowisata, evaluasi pengembangan ekowisata, serta kajian potensi mangrove (Kautsar, 2017; Mirawati, Tengku, \& Retna, 2013; Mustanto, Nasution, \& Yoswaty, 2016), sedangkan kajian mengenai pemberdayaan masyarakat melalui kegiatan ekowisata masih perlu didorong untuk memberikan pemahaman berdasarkan bukti empiris akan dampak serta manfaat dari kegiatan ekowisata bagi pemberdayaan masyarakat, khususnya pada desa-desa pesisir.

\section{B. PELAKSANAAN DAN METODE}

Jenis pendekatan yang digunakan dalam penelitian ini adalah pendekatan kualitatif dengan analisa deskriptif. Sedangkan lokasi penelitian dibatasi hanya pada 2 desa pesisir di wilayah Kabupaten Bintan, yaitu: Desa Kuala Sempang dan Desa Pengudang. Alasan pemilihan lokasi penelitian adalah karena desa-desa tersebut menerapkan konsep ekowisata, pengelolaan kegiatan ekowisata dijalankan oleh masyarakat lokal, serta desa-desa tersebut aktif sebagai destinasi ekowisata. Desa Kuala Sempang dan Desa Pengudang masing-masing memiliki kawasan ekowisata yang mencakup kawasan pesisir, hutan mangrove, serta aliran sungai.

Penelitian ini menggunakan dua metode pengumpulan data, yakni: wawancara dan observasi. Sedangkan kerangka kerja yang digunakan dalam penelitian ini diadopsi dan disesuaikan dari Kerangka Kerja Pemberdayaan Masyarakat yang terdiri dari enam faktor-faktor pemberdayaan sebagai berikut: pemberdayaan ekonomi; pemberdayaan sosial; pemberdayaan psikologi; pemberdayaan politik; pemberdayaan ekologi; dan pemberdayaan pengunjung. Sedangkan indikator yang digunakan, 
bersumber dari UNEP dan UNWTO (Winkler \& Zimmermann, 2014).

\section{HASIL DAN PEMBAHASAN}

\section{Pemberdayaan di Desa Kuala Sempang}

Pada saat penelitian ini dilakukan, pengelolaan ekowisata dengan skema $\mathrm{HKm}$ oleh masyarakat di Desa Busung dan Desa Kuala Sempang sudah tidak berjalan semenjak tahun 2017 (Purnomo, Ramdani, Setyadiharja, \& Muzwardi, 2018). Namun, pengelolaan kegiatan ekowisata mulai dirintis kembali oleh Ballond Mangrove Tour pada bulan Februari tahun 2019 hingga penelitian ini dilaksanakan. Hanya saja, jika kegiatan ekowisata yang sebelumnya dijalankan dengan melalui skema $\mathrm{Hkm}$ di Desa Busung dan di Desa Kuala Sempang, sekarang ini, kegiatan ekowisata hanya berjalan dan dikelola oleh masyarakat di Desa Kuala Sempang oleh Ballond Mangrove Tour. Hingga sekarang, Ballond Mangrove Tour telah membawa 16 kelompok wisatawan dari dalam dan luar negeri menyusuri aliran sungai dan hutan mangrove di Desa Kuala Sempang.

\section{Pemberdayaan Ekonomi Kelayakan Ekonomi}

Masyarakat Desa Kuala Sempang secara keseluruhan mendapat manfaat dari dijadikannya Desa Kuala Sempang sebagai destinasi ekowisata yang dikelola oleh Ballond Mangrove Tour. Namun, dampak ekonomi dari kegiatan ekowisata di Desa Kuala Sempang belum signifikan. Hal ini terjadi karena skala kegiatan ekowisata yang dijalankan terbilang masih kecil. Hal ini dapat dimengerti karena berbeda dengan destinasi wisata konvensional yang dapat mendatangkan wisatawan dengan jumlah besar ke suatu lokasi wisata, konsep ekowisata tidak mengizinkan jumlah wisatawan yang besar untuk destinasi ekowisata atas dasar menjaga kelestarian alam dari eksploitasi pengelola dan perusakan oleh pengunjung.

\section{Kemakmuran Masyarakat Lokal}

Dikarenakan oleh skala ekonomi destinasi ekowisata yang masih terbilang kecil, manfaat dari ekowisata di Desa Kuala Sempang untuk kemakmuran masyarakat lokal masih belum merata. Namun, walaupun begitu, hal ini bukan berarti bahwa kegiatan ekowisata tidak membawa kemakmuran bagi masyarakat lokal. Ballond Mangrove Tour dalam hal ini, berkontribusi positif dengan membangun kerjasama di Desa Kuala Sempang. Kerjasama ini dibangun dengan memberdayakan masyarakat lokal dalam menyediakan kuliner khas wilayah pesisir seperti ikan, udang, kepiting dan makanan laut lainnya dirumah makan bagi wisatawan. Disamping itu, Ballond Mangrove Tour juga memberdayakan peternak lebah madu tradisional di Desa Kuala Sempang dengan memasukkan lokasi peternakan lebah madu tradisional dalam rute perjalanan. Wisatawan dapat melihat bagaimana lebah madu diternakkan, dan bahkan dapat membeli madu alami secara langsung dari peternak lebah madu tradisional tersebut. Nelayan penangkap kepiting tradisional disekitar sungai juga diberdayakan oleh Ballond Mangrove Tour dimana rute perjalanan juga akan singgah untuk melihat bagaimana nelayan tradisional menangkap kepiting di sungai dengan menggunakan bubu atau alat tangkap kepiting.

\section{Kualitas Pekerjaan}

Kualitas pekerjaan yang ditawarkan oleh kegiatan ekowisata di Desa Kuala Sempang dirasa cukup memuaskan. Ballond Mangrove Tour memberdayakan masyarakat lokal dengan cara merekrut guide atau pemandu tour, serta tekong kapal atau pengemudi kapal dari pemuda-pemuda disekitar Desa Kuala Sempang. Tidak hanya itu, bagi mereka yang berminat untuk 
menjadi pemandu tour ekowisata, Ballond Mangrove Tour bahkan memberikan pelatihan Bahasa Inggris serta menyediakan manual tour untuk dipelajari.

\section{Pemberdayaan Sosial \\ Keadilan Sosial}

Kegiatan ekowisata belum dapat meningkatkan keadilan sosial di Desa Kuala Sempang. Hal ini dikarenakan oleh kegiatan ekowisata yang di kelola oleh Ballond Mangrove Tour baru berjalan pada bulan Februari tahun 2019, sehingga belum dapat memberikan dampak signifikan bagi keadilan sosial pada masyarakat lokal. Harapan kedepan adalah, dengan bertambahnya wisatawan yang berkunjung, keadilan sosial ditengah-tengah masyarakat akan lebih tercipta dengan terbukanya potensi ekonomi bagi masyarakat untuk berpartisipasi.

\section{Kesejahteraan Masyarakat}

Kegiatan ekowisata yang dikelola oleh Ballond Mangrove Tour berkontribusi terhadap kesejahteraan masyarakat, namun belum merata. Secara umum, kegiatan ekowisata menyediakan beberapa pekerjaan dan pemasukan tambahan bagi masyarakat lokal diantaranya adalah: sebagai pemandu (guide), atau sebagai tekong kapal (pemandu kapal). Disamping itu, kerjasama yang dijalin dengan kelompok petani lebah madu tradisional juga sedikit banyak dapat meningkatkan pendapatan dari pembelian madu lebah oleh wisatawan.

\section{Pemberdayaan Psikologi}

\section{Kekayaan Budaya}

Kegiatan ekowisata seharusnya juga dapat mendorong pengenalan akan budaya dan nilai-nilai masyarakat lokal, namun, hal tersebut belum dapat sepenuhnya dicapai di Desa Kuala Sempang. Tantangan untuk hal ini adalah belum terintegrasinya kegiatan ekowisata dan kegiatan kebudayaan di Desa Kuala Sempang. Kegiatan ekowisata di Desa Kuala Sempang fokus pada aspek eksplorasi kekayaan alam seperti hutan mangrove dan aliran sungai, dan belum menyentuh kekayaan budaya serta nilai-nilai masyarakat lokal.

\section{Pemberdayaan Politik \\ Kendali Masyarakat Lokal}

Kegiatan ekowisata di Desa Kuala Sempang belum dapat berkontribusi dalam meningkatkan partisipasi politik masyarakat lokal. Hal ini terjadi karena fokus kegiatan ekowisata di Desa Kuala Sempang adalah pada konservasi ekosistem hutan mangrove dan sungai, serta pada peningkatan ekonomi masyarakat lokal. Namun begitu, masyarakat lokal memiliki kendali atas kegiatan ekowisata yang berjalan di Desa Kuala Sempang. Bentuk kendali masyarakat ada pada perlibatan masyarakat dalam kegiatan-kegiatan ekowisata hingga perlibatan masyarakat lokal dalam kegiatankegiatan konservasi yang dilakukan di Desa Kuala Sempang.

\section{Dampak Pengembangan Ekowisata Pemberdayaan Ekologi \\ Integritas Fisik}

Kegiatan ekowisata di Desa Kuala Sempang sedikit banyak mempengaruhi integritas fisik masyarakat lokal dan lingkungan sekitarnya. Pengaruh kegiatan ekowisata terletak pada kegiatan konservasi yang digalakkan ditengah-tengah masyarakat untuk mempertahankan dan menjaga keasrian serta keanekaragaman hayati ekosistem yang ada di Desa Kuala Sempang.

\section{Keanekaragaman Hayati}

Kegiatan ekowisata berkontribusi terhadap kelestarian keanekaragaman hayati dilingkungan sekeliling Desa Kuala Sempang. Kegiatan ekowisata bergantung pada kelestarian keanekaragaman hayati, oleh karenanya, Ballond Mangrove Tour memiliki tanggungjwab untuk menjaga kelestarian alam. Ballond Mangrove Tour melakukan upaya-upaya konservasi dalam 
setiap tour yang dijalankan. Hal ini dilakukan dengan memberikan edukasi dan pemahaman kepada para wisatawan tour yang berkunjung.

\section{Efisiensi Energi}

Kegiatan ekowisata sejatinya harus juga menerapkan prinsip efisiensi energi dalam setiap kesempatan. Hal ini seharusnya juga tidak luput dari perhatian Ballond Mangrove Tour. Namun, berdasarkan observasi, Ballond Mangrove Tour dalam setiap kegiatan tour mencoba untuk menerapkan prinsip efisiensi. Hanya saja, dalam implementasinya penggunaan bahan bakar fosil seperti bahan bakar diesel untuk transportasi tour, belum dapat dihindarkan penggunaannya untuk saat ini.

\section{Pemberdayaan Pengunjung Kepuasan dan Pendidikan Pengunjung}

Usaha konservasi alam dijalankan oleh Ballond Mangrove Tour untuk menjaga agar ekosistem hutan mangrove dan aliran sungai terjaga keasriannya dan terhindar dari perusakan. Disamping menikmati keindahan alam hutan mangrove, wisatawan diberikan edukasi mengenai ekosistem sekitar aliran sungai disertai dengan penjelasan dari para pemandu yang terlatih. Usaha-usaha konservasi yang dilakukan membuat pengunjung memberikan apresiasi kepada pengelola kegiatan ekowisata. Tidak hanya itu, pengunjung juga merasa puas dapat berinteraksi dengan masyarakat lokal walaupun terkendala dengan tantangan perbedaan bahasa.

\section{Pemberdayaan di Desa Pengudang}

Destinasi wisata di Desa Pengudang, Kecamatan Telok Sebong, Kabupaten Bintan, dapat dikatakan berbeda karena sebagai destinasi wisata, pengelolaannya tidak dilakukan oleh perusahaan multinasional seperti destinasi wisata lainnya di Bintan. Pengudang Bintan Mangrove mengelola destinasi ekowisata di Desa Pengudang semenjak tahun 2017 dengan menggunakan prinsip community based tourism dimana pihak pengelola destinasi ekowisata mengedepankan pemberdayaan masyarakat pada komunitas masyarakat lokal yang umumnya berprofesi sebagai nelayan.

\begin{tabular}{lcr}
\multicolumn{1}{c}{ Sebagai } & \multicolumn{2}{c}{ pengelola destinasi } \\
ekowisata & yang & mengedepankan \\
pemberdayaan & pada & masyarakat lokal,
\end{tabular} Pengudang Bintan Mangrove telah berhasil menjadikan Desa Pengudang sebagai destinasi ekowisata yang dikunjungi oleh sekitar 1500 pengunjung dengan komposisi $70 \%$ wisatawan lokal, dan $30 \%$ wisatawan asing dalam beberapa tahun terakhir. Kunjungan wisatawan, baik lokal maupun asing, telah sedikit banyak membantu meningkatkan perekonomian masyarakat lokal. Selain sebagai pengelola destinasi ekowisata, Pengudang Bintan Mangrove melalui paket tournya juga mengkampanyekan pelestarian lingkungan, khususnya lingkungan sekitar tanaman mangrove, dan wilayah pesisir dengan tujuan konservasi alam serta menjaga agar ekosistem hutan mangrove dan pesisir terlindungi dari perusakan.

\section{Pemberdayaan Ekonomi}

\section{Kelayakan Ekonomi}

Masyarakat Desa Pengudang secara keseluruhan mendapat manfaat dari kegiatan ekowisata yang dikelola oleh Pengudang Bintan Mangrove. Namun, dampak dari kegiatan ekowisata belum signifikan. Masyarakat lokal saat ini belum mendapatkan manfaat ekonomi secara signifikan dikarenakan oleh skala ekonomi kegiatan ekowisata yang dikelola oleh Pengudang Bntan Mangrove terbilang kecil. Hal ini dapat dimengerti, karena berbeda dengan destinasi wisata konvensional yang dapat mendatangkan wisatawan dengan jumlah signifikan ke suatu lokasi wisata, konsep ekowisata tidak mengizinkan jumlah wisatawan yang besar untuk berkunjung ke 
destinasi ekowisata dengan alasan untuk menjaga kelestarian alam dari eksploitasi pengelola dan perusakan oleh pengunjung.

\section{Kemakmuran Masyarakat Lokal}

Pengudang Bintan Mangrove berkontribusi positif dalam meningkatkan kemakmuran masyarakat lokal dengan memberdayakan masyarakat lokal dalam menyediakan masakan atau kuliner khas wilayah pesisir seperti ikan, udang, ketam, kerupuk ikan dan udang, serta kuliner khas lainnya.

\section{Kualitas Pekerjaan}

Kualitas pekerjaan yang ditawarkan oleh kegiatan ekowisata di Desa Pengudang dirasa cukup memuaskan. Pengudang Bintan Mangrove memberdayakan masyarakat lokal dengan cara merekrut guide atau pemandu tour, serta tekong kapal atau pengemudi kapal dari pemuda-pemuda disekitar Desa Pengudang. Tidak hanya itu, mereka yang direkrut untuk menjadi pemandu tour ekowisata bahkan diberikan pelatihan Bahasa Inggris untuk memudahkan komunikasi bersama wisatawan luar negeri. Saat penelitian ini dilakukan, setidaknya Pengudang Bintan Mangrove memiliki 3 guide yang berasal dari masyarakat lokal Desa Pengudang.

\section{Pemberdayaan Sosial}

Keadilan Sosial

Kegiatan ekowisata di Desa Pengudang belum dapat meningkatkan keadilan sosial ditengah-tengah masyarakat secara signifikan. Hal ini dikarenakan oleh kegiatan ekowisata yang dikelola oleh Pengudang Bintan Mangrove baru berjalan lebih kurang 2 tahun, sehingga belum dapat memberikan dampak menyeluruh bagi keadilan sosial pada masyarakat lokal. Harapan kedepan adalah, dengan bertambahnya jumlah wisatawan yang berkunjung ke Desa Pengudang, keadilan sosial ditengah-tengah masyarakat akan lebih tercipta dengan terbukanya potensi ekonomi bagi masyarakat untuk berpartisipasi.

\section{Kesejahteraan Masyarakat}

Kegiatan ekowisata yang dikelola oleh Pengudang Bintan Mangrove berkontribusi terhadap kesejahteraan masyarakat, namun kontribusi tersebut belum merata. Secara umum, kegiatan ekowisata menyediakan beberapa pekerjaan dan pemasukan tambahan bagi masyarakat lokal diantaranya adalah: sebagai pemandu (guide), atau sebagai tekong kapal (pemandu kapal). Disamping itu, kerjasama yang dijalin dengan nelayan-nelayan lokal, serta dengan usaha mikro lokal, sedikit banyak membantu meningkatkan pendapatan masyarakat lokal. Diharapkan kedepannya Pengudang Bintan Mangrove dapat meningkatkan skala kegiatan ekowisata agar dapat meningkatkan kesejahteraan masyarakat lokal di Desa Pengudang.

\section{Pemberdayaan Psikologi}

Kekayaan Budaya

Kegiatan ekowisata diharapkan juga dapat mendorong pengenalan akan budaya dan nilai-nilai tradisional yang dianut oleh masyarakat lokal, namun, hal tersebut belum dapat sepenuhnya dicapai di Desa Pengudang. Tantangan untuk hal ini adalah belum terintegrasinya kegiatan ekowisata dan kegiatan kebudayaan di Desa Pengudang. Namun, Pengudang Bintan Mangrove sudah memulai mencoba untuk menyentuh aspek kebudayaan dengan diangkatnya kebudayaan khas Melayu. Hal ini dilakukan dengan memberikan dorongan kepada generasi muda di Desa Pengudang dalam berbagai kegiatan untuk mendorong pementasan kreasi tari melayu, pencak silat, dan kesenian kompang.

Pemberdayaan Politik Kendali Masyarakat Lokal

Kegiatan ekowisata di Desa Pengudang belum dapat berkontribusi dalam meningkatkan partisipasi politik masyarakat 
lokal secara menyeluruh. Hal ini terjadi karena fokus kegiatan ekowisata di Desa Pengudang adalah pada konservasi ekosistem hutan mangrove dan sungai, serta pada pemanfaatan potensi ekonomi masyarakat lokal. Namun yang patut diapresiasi adalah masyarakat lokal memiliki kendali atas kegiatan ekowisata di Desa Pengudang. Bentuk kendali ini ada pada pemberdayaan masyarakat lokal yang dilibatkan dalam kegiatan ekowisata dimana masyarakat lokal direkrut sebagai pemandu atau pengemudi kapal, dilibatkan upaya konservasi, serta dilibatkan dan menjadi bagian dari tujuan-tujuan ekowisata.

\section{Dampak Pengembangan Ekowisata}

Masyarakat lokal sadar akan tujuan dan nilai-nilai yang dibawa oleh kegiatan ekowisata. Kerapuhan alam dan ekosistem, serta kesenjangan sosial masyarakat, diharapkan dapat terekspose dari kegiatan ekowisata. Pengudang Bintan Mangrove juga melakukan pendekatan-pendekatan dengan menanamkan nilai-nilai konservasi yang dimulai dari tindakan-tindakan sederhana, seperti untuk tidak membuang sampah dilaut atau disungai. Tindakan sederhana ini merupakan langkah baik untuk memulai tahapan-tahapan peningkatan kesadaran ke masyarakat lokal bahwa ekosistem dan alam di Desa Pengudang harus dijaga oleh masyarakat.

\section{Pemberdayaan Ekologi Integritas Fisik}

Pengudang Bintan Mangrove peduli dengan kegiatan konservasi, salah satunya adalah konservasi Dugong. Dugong adalah icon Kabupaten Bintan dan keberadaan hewan langka ini masih dapat ditemui di perairan Desa Pengudang. Dengan diperkuat oleh penelitian dari LIPI (Lembaga Ilmu Pengetahuan Indonesia), UMRAH (Universitas Maritim Raja Ali Haji), serta DSCP (Dugong Seagrass Conservation Project) yang telah cukup intens berkomunikasi dengn Pengudang Bintan Mangrove, diharapkan kedepannya Desa Pengudang dapat menjadi pusat penelitian serta eduwisata di Kabupaten Bintan dengan memiliki Dugong Centre.

\section{Keanekaragaman Hayati}

Pengudang Bintan Mangrove melakukan upaya-upaya konservasi dalam setiap kegiatan tour yang dijalankan. Hal ini dilakukan dengan memberikan edukasi serta pemahaman kepada wisatawan yang berkunjung bahwa ekosistem hutan mangrove, aliran sungai, dan pantai adalah ekosistem yang rawan akan perusakan oleh manusia. Pengudang Bintan Mangrove bahkan mengajak masyarakat lokal untuk ikut melestarikan ekosistem yang rapuh di Desa Pengudang dengan memberikan contoh bahwa alam yang terjaga dapat mendatangkan keuntungan ekonomi kepada masyarakat lokal.

Pengudang Bintan Mangrove juga menjadi core team World Cleanup Day Provinsi Kepulauan Riau dan koordinator aksi Pesisir Timur Bintan dengan mengajak berbagai elemen masyarakat untuk membersihkan laut dan pantai, menanam bibit-bibit tanaman mangrove, serta melakukan edukasi dalam setiap kesempatan baik secara verbal melalui tour guide, maupun secara visual melalui gambargambar flora dan fauna yang terdapat di ekosistem hutan mangrove, aliran sungai, pantai, serta laut.

\section{Efisiensi Energi}

Kegiatan ekowisata sejatinya harus menerapkan prinsip efisiensi energi dalam setiap kesempatan. Hal ini seharusnya juga tidak luput dari perhatian Pengudang Bintan Mangrove dalam setiap kegiatan ekowisata yang dijlankan. Namun, berdasarkan observasi, Pengudang Bintan Mangrove dalam setiap kegiatan tour mencoba untuk menerapkan prinsip efisiensi energi. Hal ini terlihat dari basecamp atau office Pengudang 


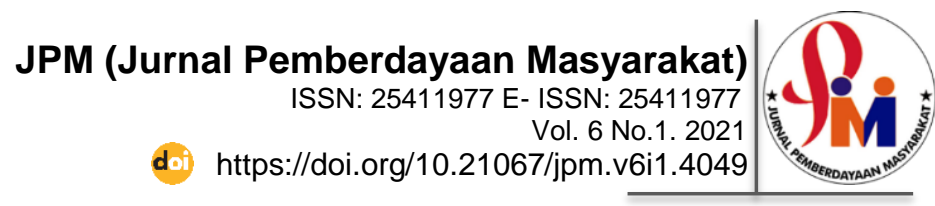

Bintan Mangrove yang sederhana dengan desain bangunan terbuka yang terbuat dari kayu.

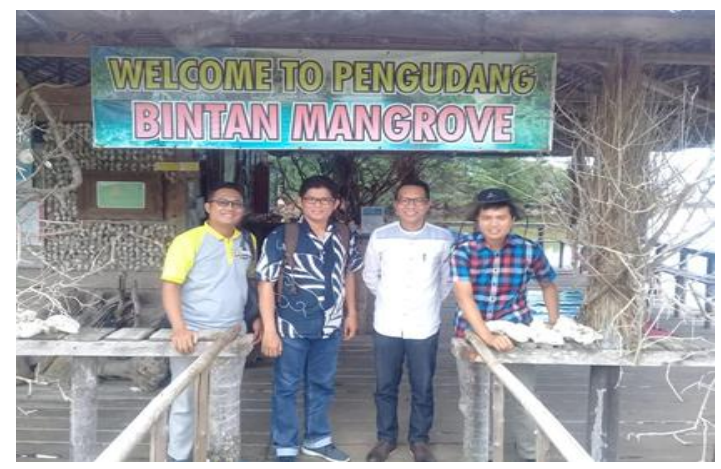

Gambar 1. Kunjungan ke Pengudang Bintan Mangrove

\section{Pemberdayaan Pengunjung} Kepuasan dan Pendidikan Pengunjung

Usaha-usaha konservasi alam dijalankan oleh Pengudang Bintan Mangrove untuk menjaga agar ekosistem hutan mangrove, aliran sungai, serta pantai terjaga terhindar dari perusakan. Lebih dari itu, disamping menikmati keindahan alam hutan mangrove, aliran sungai, serta pantai wisatawan juga diberikan edukasi mengenai ekosistem di sekitar Desa Pengudang disertai dengan penjelasan dari para pemandu yang terlatih. Usaha-usaha konservasi yang dilakukan membuat wisatawan memberikan apresiasi kepada pengelola kegiatan ekowisata di Desa Pengudang.

\section{PENUTUP}

\section{Simpulan}

Desa Kuala Sempang bersama Ballond Mangrove Tour dan Desa Pengudang bersama Pengudang Bintan Mangrove telah membuktikan bahwa kegiatan ekowisata di Kabupaten Bintan membuka peluang bagi pemberdayaan masyarakat lokal. Namun, masih diperlukan kerja keras bagi pihak pengelola kegiatan ekowisata, pemerintah desa, pemerintah daerah, serta stakeholder terkait lainnya agar manfaat dari pemberdayaan masyarakat melalui kegiatan ekowisata dapat dirasakan secara lebih luas dan merata.

\section{Saran}

Perhatian serta peran serta Pemerintah Daerah Kabupaten Bintan perlu ditingkatkan untuk menambah kapasitas pengelola ekowisata agar dapat berperan aktif memberdayakan masyarakat desa.

\section{Ucapan Terimakasih}

Penghargaan dan ucapan terimakasih yang sebesar-sebesarnya disampaikan kepada Direktorat Riset dan Pengabdian Masyarakat (DRPM)-Kementerian Riset, Teknologi, dan Pendidikan Tinggi (KEMENRISTEK DIKTI) Republik Indonesia atas pendanaan penelitian melalui skema: Penelitian Dosen Pemula (PDP) Tahun 2019.

\section{E. DAFTAR PUSTAKA}

Kautsar, W. (2017). Pengelolaan Ekowisata Mangrove di Desa Sebong Lagoi, Bintan, Kepulauan Riau. Thesis. Sekolah Pascasarjana, Institut Pertanian Bogor.

Mirawati, Tengku, E., \& Retna, M. W. (2013). Kajian Potensi Mangrove Sebagai Daerah Ekowisata di Desa Sebong Lagoi. Universitas Maritim Raja Ali Haji.

Mustanto, P., Nasution, S., \& Yoswaty, D. (2016). Evaluasi Pengembangan Ekowisata Mangrove di Desa Sebong Lagoi Kabupaten Bintan Provinsi Kepulauan Riau. Jurnal Online Mahasiswa (JOM) Bidang Perikanan 


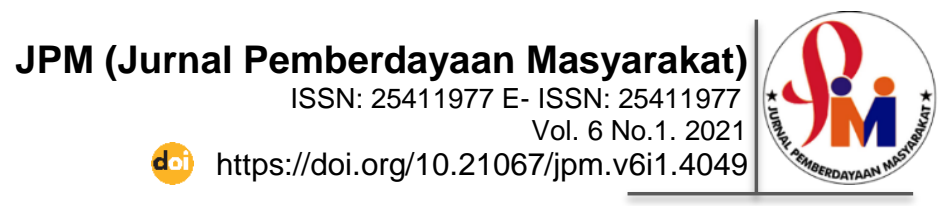

dan Ilmu Kelautan, 3(2).

Nazarullail, F., Hardika, \& Desyanty, E. S. (2017). Pemberdayaan Masyarakat Melalui Program Ekowisata "Lepen Adventure." Jurnal Pendidikan: Teori, Penelitian, Dan Pengembangan, 2(8), 1071-1076.

Purnomo, E. P., Ramdani, R., Setyadiharja, R., dan Muzwardi A. (2018). Collaborative Governance Dalam Tata Kelola Hutan Berbasis Masyarakat. Penerbit: LP3M Universitas Muhammadiyah Yogyakarta. Yogyakarta.

Winkler, T., \& Zimmermann, F. (2014). "Ecotourism as Community Development Tool: Development of an Evaluation Framework". Current Issues of Tourism Research, 4(2), 45-56. 